\title{
Engagement as a Variable to Improve the Relationship between Leadership, Organizational Culture on the Performance of Employees
}

\author{
Yupono Bagyo \\ (STIE Malangkucecwara, Malang, Indonesia)
}

\begin{abstract}
Employee Performance Management is a process for establishing a shared workforce understanding about what is to be achieved at an organisation level. Many factors affect the performance of the employees, in which performance of the employees affected attitudes, organizational commitment, organizational citizenship behavior and this study focuses on employee engagement work services sector. Data was collected from employees in Lawang Medica one of Hospital, in Malang Indonesia. The survey questionnaire was designed to collect information concerning three areas of management constructs: Leadership, Corporate Culture, Engagement and Performance. In order to minimize the potential bias, There were intelligence, maturity and breadth of social relationships, self motivation and encouragement of achievement, attitudes human relations questions pertaining to leadhersip, questions about functional culture, process - driven culture, time - based cultures, network cultures, for corporate culture, 3 questions: Career Roadmap (Planning and Tracking, Career Coaching on Demand, Internal Mobility (Jobs and Gigs, Networking and Community, Company Groove for engagement, and 3 questions: Timeliness in completing the task, Completion of employment, work without error for performance, to refine the analysis, the research comes with a Sony voice recorder type ICD-UX512F used to search for the clarity of the argument to the informant on the acceptance or rejection of the hypothesis. The result is a leadership influence on engagement, corporate culture and employee performance. This leadership influence will increase if the variables included engagement of employees. Interesting finding of this study is the high performance of employees can not be said to be due to the influence of culture ccorporate, but because of variable engagement, corporate culture influences the performance will be meaningful. This suggests that the importance of engagement in an organization.
\end{abstract}

Keywords: Leadhersip, Corporate Culture, Engagement, Performance.

\section{Introduction}

High employee performance can not be separated from the ways in leading employees organizations, Individual performance is influenced by the ability, skills, knowledge, attitudes, motivation and job stress (Gibson et. al. 2000), while other studies say that the performance of the individuals affected by the existence of the soul organizational citizenship behavior and commitment organisasinal (Yupono, 2009) as well as the intelligence of the leadership in managing subordinates through customs, beliefs and willingness based on standard operating procedures are implemented in the organizational culture. Another very important aspect in driving performance is profound willingness of employees described in the sub-culture in health care, doctors, nurses and management which has different characteristics, such as: relationship with the environment, reality and truth, the basis of humanity, the relationship between private. This difference can be seen by the character of their ability and willingness to help fellow co-workers or friends within the organization for smooth running of the organization that is described in the engagement. Engagement may constitute the mechanism through which HRM practices impact individual and organisational performance. However, engagement has emerged as a contested construct, whose meaning is susceptible to 'fixing, shrinking, stretching and bending'. (Truss, at, al, 2013).

From the description above, the problem is formulated and tested at the same time: a). leadership in service companies to improve the performance of its employees, b). leadership can influence organizational culture, c). organizational culture can improve the performance of the employees, d). engagement can improve performance, e). engagement can improve leadership and organizational culture on performance

\section{Leadership}

Leadership is a special case of interpersonal influence that gets an individual or group to do what the leader wants done (Wood, at al., 2001), has two important roles, namely: 1). Complete the task, is the main objective in the establishment of a group led by its leader. Leaders must ensure that the group's objective will be achieved. If not achieved, it will cause frustration, disharmony, criticism and the disintegration of the group.2). Maintain effective relationships, ie relationships with members of the group leader and the ridge between group 
members. A relationship is called effective if the relationship is contributing to the performance employees.In the relation to maintaining effective relationships, leaders are divided in two categories: First, group leader pays attention to the morale and achieving goals, Second, leaders who focus on the individual and how motivated. Suggests that effective leadership always focus on three areas of need for the team members that matter - issues related to the task (task need), things - things related to the team itself (team needs) and are related to each individual on the team ( individual needs). In any atmosphere whatsoever, emphasis on three areas can be different, but all related to each other, then each leader must be able to understand and comprehend all three . Task needs: Which includes requirements that all tasks in the process of management and organization , including the organization's mission and goals . Team needs: The needs of the team which includes everything related to the effective interaction, support, cooperation and communication within the team and with other teams . Individual needs: Which includes the individual needs of different course - the difference between one individual with another individual, yet effective leaders will pay attention to and interest in how the individual the individual interact and behave (Adair, 2010).

Of this description are at least four general properties that have an influence on the success of the organization's leadership, namely: intelligence, maturity and breadth of social relationships, self motivation and encouragement of achievement, attitudes human relations, usually found in engagement measures and goes on to explore the relationship between these elements and the performance management process: Clarity Are clear about goals received by employees, leadership support given to employees, so that employees feel proud if it had the full support of his superiors, fit its job match employee skill set in performing the task, feedback Regularly get useful feedback is given if the employee is able to demonstrate its performance dittapkan exceed standards, development opportunities to develop (CIPD-hr-profession, 2013).

\section{Corporate Culture}

Organisational culture is the system of shared beliefs and values that develops within ist sub-units, and that guides the behavior of its members (Wood, at al, 2001). Culture plays out in a variety of ways. We can identify the specifics of it from how information is communicated, feedback is given, performance is managed, and projects are co-coordinated within the organization. It is reflected in the way the corporation or institution is structured; whether work is conducted cross-functionally or within silos, how the hierarchical levels are set up, and the types of job titles used. Culture is often defined by the systems that are used, the processes that are followed, and the rituals, symbols, and stories that abound in the organization. It is even reflected in how meetings are held in an organization (Sergey Group, 2013). In practice be categorized into the following points:

1) Functional culture, focusing on individual specialization and decision making by using a corporate hierarchy so that more emphasis on reliability and consistency Organizational culture that embraces functional tended to avoid the risk, just use the methods that have been tested, serving markets that have been formed, and maintain accountability.

2) Process - driven culture, emphasis on quality and customer satisfaction and focus on processes to improve quality and meet bond to consumers . Organizations that embrace this culture has a strong commitment to the consumer to maintain their trust. Time - based cultures, trying to keep costs down and quickly put out new products and services to market. Organizations with this culture of trying to push the product cycle, develop new products and services, highly responsive and able to adapt quickly .

3) Network cultures, design work is about an alliance that has the competencies required by the organization to compete. By network cultures organization strives to develop new products and services, take advantage of all the opportunities that exist, and the effective use of resources from outside .

In functional culture, which focuses on individual specialties, the formation of culture can not be separated from the person sub culture attached to each of the existing resources . According to (Mannion, et al., 2010 ) in a sub- culture in health care, doctors, nurses and the management has a different character . this in terms of some elements such as : the relationship with the environment, reality and truth, the foundation of humanity .

Sub- culture is closely linked with the job , the work environment, such as a hospital clinical networks , and other affiliates. Therefore the resources at the hospital is very important to note, because professionals are doctors, specialists, nurses, midwives, and managers ( heads and administrative staff) because it has the characteristics and culture of each ( sub- culture). Therefore, the need for mutual adjustment to each other in order to established a cooperation and collaboration of the various professions so as to achieve the expected results or goals well . cultural characteristics of each professional medical, nursing and managerial very different (Mannion, et. al., 2001)).

The foundational nature of learning and continuous improvement cultures for engagement programs. The cycle is predicated upon cultures of learning and continuous improvement for two reasons. One, both cultures assume that something needs to be fixed. In the case of a learning culture, individuals seek to close a development gap in order to improve their performance. In a continuous improvement culture, we seek to fix 
quality issues and improve efficiencies of work processes. Similar to improving performance and work processes, when we measure engagement, we assume that we will need to adjust work practices and cultures in order to raise engagement levels. Two, both cultures use feedback. Individuals working within a learning culture readily accept feedback on a daily basis and incrementally adjust the way they work, as employees do with work process and systems within continuous improvement cultures. In these cultures, incremental change based on timely feedback is a way of life, and a practice that is foundational when engagement-supportive behaviors into the organization.

Corporate culture measured in this study of the functional culture, process driven culture, time based culture, network culture

\section{Engagement}

Engagement is the state of emotional and intellectual commitment to an organization (CBSR and

Hewitt Associates, 2010).

Employee Engagement is a measurable degree of an employee's positive or negative emotional attachment to their job, colleagues and organization that profoundly influences their willingness to learn and perform at work (http://en.wikipedia.org/wiki/Employee engagement).

The foundational nature of learning and continous improvement cultures for engagement programs. The cycle is predicated upon cultures of leaning and continous improvement for two reasons. Cultures assume that something needs to be fixed. In the case of a learning culture. Individual seek to close a developmentngap in order to improve their performance. In a continous improvement culture, to fix quality issues and improve efficiencies of work processes. Similar to improveing performance and work processes. (Zinger, 2011)

Engaged employee behavior is a consistently say positive things about the organization, intend to stay with the organization and strive to achieve above and beyond what is expected in their daily role (CBSR and Hewitt Associates, 2010).

Engagement in organizational Improvement culture can be done through Improvement culture: Individuals: Ownership, clarity and action. Individuals need to know what they want - and what the organization needs - and then take action to achieve both, Managers: Coaching, relationships and dialogue. Managers must understand each individual's talents, interests and needs and then match those with the organization's objectives - while at the same time creating personal, trusting relationships. Furthermore, they need to discuss engagement often. Executives: Trust, communication and culture. Executives have to demonstrate consistency in words and actions, communicate a lot (and with a lot of depth), and align all business practices and behaviors throughout the organization to drive results and engagement. (Blessingwhite research ,2013), engagement levels the engagement-retention connection, key drivers, and the ways that behaviors of managers and senior leaders influence engagement (Blessingwhite research, 2013).

The core elements of the RiseSmart Compass platform include (Garcia, 2013): Career Roadmap (Planning and Tracking): Employees can set their own career goals, establishing milestones and action items for ongoing career development and collaboration with others within the organization, Career Coaching on Demand: Employees can access a wealth of information and resources, organized along guided career coaching paths, Internal Mobility (Jobs and Gigs): Employees can find and apply for short- and long-term opportunities within their organization that can further their career development and positively impact retention for the corporation, Networking and Community: Employees can build closer bonds within the organization by growing their internal networks through a mentor-matching platform, community forum and internal contactmanagement tools, Company Groove: Employees can see how their colleagues are feeling about their jobs or company in real time, through a feed that highlights current satisfaction levels, HR Analytics: Employers can improve their workplace planning efforts with an organizational view of employee skills and job/gig activity, helping to ensure that employees and departments are on the right track to meet their goals.

Ways to Pump Up Employee Engagement: Have employees set their own goals and review them, Make sure goals are within your employees' control, Make sure goals are timely and measurable, Set both big and underlying goals, Leverage team accountability, Enable employees to see results in real-time, Creatively set goals when needed. (Lavinsky, 2013). This is consistent with a Engaged Workforce model, that engagement depends on : credible leadership, supportive co - workers, job and career satisfaction, high performing organization, employees commitment, high performing work force, productive and profitable organization. (http://www.talentkeepers.com/images/EngagedWorkforceModel.png).

\section{Employee Performance}

Employee Performance Management is a process for establishing a shared workforce understanding about what is to be achieved at an organisation level. It is about aligning the organisational objectives with the employees' agreed measures, skills, competency requirements, development plans and the delivery of results. 
The emphasis is on improvement, learning and development in order to achieve the overall business strategy and to create a high performance. (http://www.peoplestreme.com/what-is-performance-management.shtml)

Gibson et al. (2000) argued that the employee's performance is the result of work accomplished by the individual in relation to his position in the organization. Term achievement (achievement) is interpreted as the importance of a job, the level of skill required, progress, and rate of completion of a job.

Performance measurement is thus very important for organizations and employees themselves are Allows employees to know how they are performing, what they can improve, and in what areas they have good performance, Identifies potential problems early, Allows both employees and supervisors to communicate goals, expectations, and achievements, Evaluations are a key piece of the puzzle for future personnel issues, including discipline, compensation and promotion. (http://www.uwgb.edu/hr/training/

ClassifiedPerformanceReviewSupervisors.pdf).

\section{Factors Affecting Performance}

Mathis and Jackson (2006 ) said: a person's performance depends on three factors: the ability to do the job , the level of effort , and support provided to a person . Individual productivity is influenced by three factors: (1) innate abilities, including : talent ( Talens ), interest (interest ), personality factors ( personality factors), and physical factors (physical factors), (2) effort, covering : motivation ( motivation), work ethic (work ethtic ) , job performance, and job design, (3) encouragement, which includes : training, equipment, organizational expectations are understood, and the productivity of working groups.

Rao (1996 ) stated about some of the things that can make employees perform better: 1) the employee will work harder if felt necessary if an organization , 2). the employee feel clear about what is expected of them and when they occasionally authorized to change expectations these expectations, 3). employees feel that the organization provides opportunities for their performance to be appreciated and given rewards, 4). employees know that the organization provides opportunities and as far as possible to use their skills, 5) if the employee believed and treated with respect, that performance measurement can be done through, time liness in completing the task, namely the ability of employees complete the work on time( Mangkunagara, 2001) That performance measurement can be done through: 1) Timeliness in completing the task, namely the ability of employees complete the work on time. 2) Completion of employment if the employee exceeds the target of completing the work exceeds the target set by the organization. 3) Work without error that does not make mistakes against a requirement of employment for each employee.

The performance factors listed in the performance appraisal with phrases listed under each performance level. These phrases can be used to get you started when describing the level of performance for your employee, job knowledge, quality of work, record keeping, initiative, attentendence. The job related activities expected of a worker and how well those activities were executed. Many business personnel directors assess the employee performance of each staff member on an annual or quarterly basis in order to help them identify suggested areas for improvement (http://www.busi-nessdictionary.com/definition/employee-performance.html).

Organisations should manage employee performance with a continuous feedback system that focuses on regular, effective communication between managers and staff and minimizes bureaucracy (CHRS, 2013).

\section{Interrelationships}

As noted earlier, that in the process of improving the performance of employees, so the main role of leader and leadership nevertheless also affect organizational culture capable of scaling up and kimerja employee engagement, so the conceptual framework in this study can be drawn as follows: In connection with the above conceptual framework, the hypothesis in this study are as follows:

a. leadership in service companies improve the performance of its employees,

b. leadership able to influence the organization's culture,

c. organizational culture can improve the performance of the employees,

d. engagement can increase the impact of leadership and influence of organizational culture on performance.

\section{Research Instrument And Analysis}

Data was collected from employees in Lawang Medica one of Hospital, in Malang Indonesia. A total of 50 questionnaires were distributed in 4 departement; 45 usable questionnaires were returned, a response rate of $100 \%$. The participants answered a total of 14 questions on a 5 point Likert-scale, ranging from 1, strongly disagree, to 5 , strongly agree. The survey questionnaire was designed to collect information concerning three areas of management constructs: Leadership, Corporate Culture, Engagement and Performance. In order to minimize the potential bias, There were 4 questions pertaining to leadhersip, 4 questions for corporate culture, 3 questions for engagement, and 3 questions for performance, and besides spreading questionnaire with 5-point Likert scale, to 
refine the analysis, the research comes with a Sony voice recorder ICD-UX512F type used to search for the clarity of the argument to the informant on the acceptance or rejection of the hypothesis.

\section{Data Analysis}

The data is collected and then tabulate the data and statistical processes used SPSS version 17 to determine the relationship Relationship with Engagement Leadership, Leadership with corporat Culture, Leadership with Performance, then also measure the relationship between Corporate Culture and Performance Engagemen. The results are presented in Table 1 in the form of direct relationship recap and direct relationship below.

Table 1.: direct relationship and direct relationship

\begin{tabular}{|c|l|c|c|c|c|}
\hline No & \multicolumn{1}{|c|}{ Relationship } & Direct & p-value & \multicolumn{2}{|c|}{ Indirect } \\
\hline 1 & Lead - Enga & 0,592 & 0,000 & & \\
\hline 2 & Lead - CorCul & 0,297 & 0,047 & & \\
\hline 3 & Lead - EmpPerf & 0,202 & 0,045 & & \\
\hline 4 & Enga - EmpPerf & 0,687 & 0,000 & & 0,204039 \\
\hline 5 & CorCul - EmpPerf & 0,056 & 0,231 & $0,297 \times 0,687$ & 0,513264 \\
\hline 6 & Lead - Enga - EmpPerf & & & $0,592 \times 0,867$ & 0,024864 \\
\hline 7 & Lead - CorCul - EmpPerf & & & $0,444 \times 0,056$ & 0,090593 \\
\hline 8 & Lead - CorCul - Enga & & & $0,297 \times 0,444 \times 0,687$ & 0,305028 \\
\hline 9 & CorCul - Enga - EmpPerf & & & $0,444 \times 0,687$ & \\
\hline
\end{tabular}

Note: Lead $=$ Leadership, Enga $\quad=$ Engagement, $\mathrm{CorCul} \quad=$ Corporate Culture EmpPerf $=$ Corporate Culture

\section{Results}

\section{1. leadership in service companies improve the performance of its employees}

Leadership influence on employee performance $(.202 ;$ P.0 , 047$)$ is considered a leader in having the ability to lead subordinates strongly agree ( $37.8 \%$ ) although most of the respondents think that good leadership ( $48 \%$ ) had a big hand in encouraging employees to performance by good. Service organization is very complicated problem, considering each piece has its own expertise was compared with other parts, so often they felt most important and instrumental in the organization consists of several parts. Such circumstances require leadership with good intelligence to guide, direct, supervise as well as a warning to any member in a way that does not offend elegant ttapi acceptable to all sections. Thus leadership is in need of maturity and breadth of social relationships by way of listening carefully to all the complaints of employees in all lines of work complaints better relationships with co-workers or family complaints, such as family problems ranging from such family. The employee problems require self motivation skills are high, because it is not uncommon modest complaints are not important can develop into all of the lines and will ultimately lower the overall performance . From such experiences to leadership must be able to perform encouragement of achievement , attitudes human relations. in addition, the existing leadership style encourages employees to work with high engagement $(0.592$, P.0, 000$)$ are indicated by the high employees in the use of time working with both ( $37.80 \%$ ). This leadership will improve the performance of the employee if the employee has a sense of engagement is high ( 0.204$)$, although the engagement is able to increase the influence of leadership on performance, but should watch out for leadership with a very good human relationships membuan some employees if there is a problem, he reported to the leadership lasung sehigga their immediate superiors they felt bypassed, so that he became indifferent in carrying out duties as head of the section.

\section{2. leadership able to influence the organization's culture,}

The relationship between the organization's leadership culture $(0.297, \mathrm{p}=0.047)$. This shows that the leadership is able to influence the shape organizational culture. All forms, behaviors, actions and greeting the leader will be seen and heard and will be a form of behavior and actions of employees. Good leadership by employees, to reduce such problems is often done in a briefing meeting of leaders deliver messages if any problems should be reported immediately leadership (no need to go through the head section). In development are often subordinate directly report to the leadership and employee satisfaction over actions such leadership model. So that the organization can run even without an existing job description. we asked the head nurse: why nurses do not fill out their activities in a computerized management information system? The head nurse replied tired of constantly reminding us to nurse. (recorder code: Z0000029.mp3) Answer This reinforces earlier theories that the effect of leadership on organizational culture, and in this case the organizational culture 
is good, because the lack of sharpness leadership in escorting employee, then the employee will do as they wish and do not ignore the rules.

\section{Organizational culture can improve the performance of the employees,}

SPSS results show the relationship of organizational culture with the performance of the employees ( $0.056, \mathrm{p} 0.231$ ), of the results shows that the relationship of organizational culture with the performance of the employees is very small and not significant. Not meaningless relationships is because the organizational culture through the relationship with the environment, reality and truth, the foundation of humanity is not running smoothly. Stout encountered because leadership is considered good, because ignorance of top management , employees who have frequent problems often report directly to top management, who should he face or head to head unit first. This situation gradually became a habit and on the other hand their boss or the head of the head unit was passed, which they are supposed to coaching members to the employees. Thus the environment will form the employees who do not respect their superiors because they be directly to the top leadership of the first report to the head or to the fist unit. Such circumstances would undermine the performance of the head portion and the head unit because they thought they were just a name rather than as head of state or head unit. These results corroborate the findings that organizational culture can not improve the performance of employees. II field of human resources director who complained to the head of Accounting (recorder code: Z0000033.mp3)"I am concerned about why things concerning resourcess I was not consulted by top management;' not responsible if employees to work as they please is not working based on standard operation procedure "engagement can increase the impact of leadership and influence of organizational culture on performance.

\section{Relationship Leadership and Engagement}

Employee engagement is very good, visible from their perception that the network considered common $(55 \%)$ shows that employees working in earnest, working based on standard operational procedure $(37.80 \%)$, although they continue to learn through their work environment, they will have a high engagement when lingungan enough support (26.70\% agree and $44.45 \%$ agree strengly), other than that, a sense of engagement demonstrated by their ability to take advantage of working with a good time (37.8\% agree and strongly agree 37 , 80\%).

Engaged employee behavior is a consistently say positive things about the organization, intend to stay with the organization and strive to Achieve above and beyond what is expected in their daily role.

Executives have to Demonstrate consistency in words and actions, communicate a lot (and with a lot of depth), and align all business practices and behaviors throughout the organization to drive results and engagement. All of these actions resulted in a relationship strong leadership and engagement $(0.592$, P.0, 000).

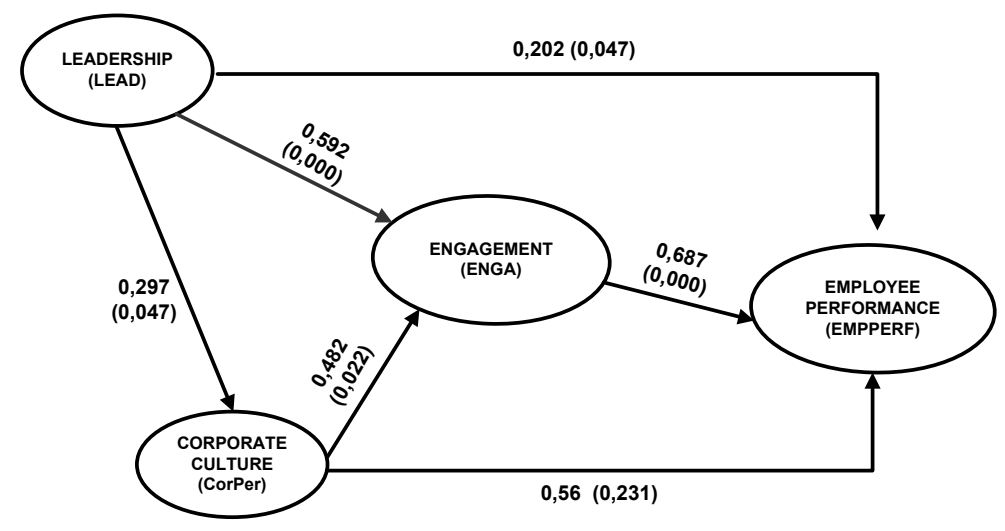

Leadership in addition to a positive impact on performance, but also still found a weakness in leadership when linked with the corporate culture.

\section{Relationship Leadership and Corporate Culture}

Relationship Proven Leadership and corporate culture has a significant impact ( 0.297, P.0, 047 ) this happens because nearly all corporate leadership in managing organizational behavior can be reflected in the behavior portrayed in the corporate culture . Leadership behavior will be followed by employee behavior, because he felt that if the behavior is not as expected leadership, they will get a judgment that they are employees who work unusual per workplace. The ability to lead is the ability of leaders to influence employee behavior . 
Leadership tends to be very familiar frequent cause bias among leaders who lead organizations with leaders who act as parents to their children. These circumstances will result in an unproductive work culture because he works alone does not work as a solid team. As expressed by one of the employees (recorder code: Z0000031.mp3 ) " Father of the deputy director of the Administration, Finance and Public works as a board member in a State, just keep an eye bekerjaya can not act, while providing guidance director, received a report from all employees arrive at a decision without a father know ". Thus occurred the opinion that the minds of the leadership model of leadership exercised without coordination and clear division of labor will be seen and felt by employees and lead to habits that will shape the culture within the organization.

Leadership influence of organizational culture is small ( 0.297, P. 0,047$)$ would thus be less solid organizational culture and will result in an unsatisfactory performance $(0.056$, P.0, 231$)$, but because of the behavior of individual employees as outlined in the engagement is high, organizational culture with respect to engagement remains to encourage employees to perform well ( 0.204 ). Attitude of employees who work sincerely with faiths that their work is an obligation that they do it with pleasure and high responsibility, would eliminate all surrounding influences, including leadership and organizational culture in both positive and negative, so engagement can increase of the impact of leadership and influence of organizational culture on performance

\section{Conslusion}

Leadership is key to the success of an organization described in employee performance. Leadership that encourages employee in a positive direction, causing a clear informative, supported by the human development by karieer and rewards which will obviously increase the performance of employees.

Employee performance depends on how the leadership in directing his boss, motivate, encourage, and reward given to subordinates. Directs subordinates how to achieve the expected performance of employees is the same as what is expected by the organization that is working to achieve optimal results, without the slightest errors can be done by way of coaching that are familial carefully so that employees feel happy and proud with his superior leadership style. Thus the way leadership is directly able to motivate and encourage subordinates to work with the maximum . For maximum performance amplifier employees are given a satisfactory reward, can be either intrinsic or extrinsic rewards. Leadership that uses models as parents to guide their children are very likely to be out of the role of structure in the organization of the system set out in standard operating procedures. Leadership model will thus encourage habits of employees and at the same time will create a culture of organizations.

Organizational culture is the main pillar that shape the behavior, ethics and the handle all employees, so that when the organizational culture of leadership that is formed by accident can change behavior, organizational culture can not significantly affect the performance, but the performance still could be improved if employee engagement has high, employees are still working fine no terengaruh by the existing culture .

Leadership addition to an effect on performance also affects the engagement. Leadership that encourages employee morale emotionally, able meningkatkanku employee awareness of the functions that they entailed and work according to the procedure as well as in the time-honored way to work. Appreciating the time is closely associated with the work, and if deemed necessary they make network with friends or friends in other parts of the work in order to be completed in accordance with the targets set, this is reflected in the engagement

Engagement owned by employees is the main factor that should be on employees and must be properly managed by the organization, because engagement can improve employee performance despite a leadership that is not conducive whichnot can improve employee performance and employee performance as well dapatmeningkatkan despite organizational culture that is formed does not support maximum performance.

Employees need a sense of employee involvement in work, because consciousness and high sense of responsibility of the employee to encourage good performance and is not affected by any of the outside environment, including a lack of leadership help drive performance improvement and organizational culture does not support the performance, employees in good performance.

\section{References}

[1] Adair, J. 2010. Decision Making and Problem Solving Strategies:Learn Key Problem Solving Strategies; Sharpen Your Creative Thinking Skills; Make Effective Decisions, Kogan Page Publishers. San Francisco.

[2] Bacal, Robert and Douglas Max, 2003, Perfect Phrases for Performance, McGraw-Hill Companies, Inc.

[3] Blessingwhite research ,2013, Employee Engagement, research update, http:// www.blessingwhite.com/EEE_report.asp

[4] CBSR and Hewitt Associates, 2010, Engaging Employees Through CSR, http:// sustainabilityadvantage.com/wpcontent/uploads/2010/10/Employee-Engagement- Defined.png

[5] CHRC, 2013, http://www.culturalhrc.ca/hrtools/06-e.asp

[6] CIPD-hr-profession, 2013, https://www.cipd.co.uk/cipd-hr-profession/hr-profession-map/professional-areas/

[7] Cummings, P.W. 1999, Open Management: Guides to Successful Practice, Amacom. New York. 
[8] Davis, K\& Newstorm, JW.2002, Human Behavior at Work Organizational, Mc Graw Hill Inc. New York.

[9] Dawson, C .2002, Metode Penelitian Praktis, How to Books Ltd, Penerbit Pustaka Pelajar. Yogyakarta.

[10] Garcia, Rob, 2013, http:/www.risesmart.com/buzz/press-releases/risesmart-introduces-risesmart-compass-groundbreaking-newapproach-employee

[11] Gibson, James L., John M. Ivancevich dan James H. Donnelly. 2000, Organization; Behavior, Structure, Process. New York: Richard D. Irwin.

[12] Katz,D .2006, The motivational basis of organizational behavior .Journal of Helath Management.

[13] Lavinsky, Dave, 2013, 7 Ways to Pump Up Employee Engagement In Your Office, http://www.entrepreneur.com/article/228583\#ixzz2h6UDFWmZ

[14] Leadership Insight, 2009, Organisational Effectiveness \& Employee Engagement, Right Management Inc. Level 6, 312 St Kilda Road Melbourne Vic 3004 www.right.com, a Manpower Company, New Zeland http://www.rightmanagement.co.nz/thoughtleadership/research/organisational-effectiveness-and-employee-engagement-discovering-how-to-make-them-happen.

[15] $\quad \ldots \ldots \ldots \ldots \ldots \ldots \ldots, 2010$, Employee Engagement, Right Management, Management Inc. 1818 Market Street, 33rd Floor Philadelphia, PA 19103-3614, www.right.com, Product \#6201-1 A MANPOWER COMPANY, New Zeland, (https://www.right.com/thought-leadership/research/employee-engagement---maximizing-organizational-performance.pdf)

[16] Mangkunegara, Anwar, Prabu, 2001, Manajemen Sumber Daya Manusia, Perusahaan. Cetakan Keenam. Bandung, Penerbit PT. Remaja Posdakarya.

[17] Mannion R, Davies H, Marshall MI, Scott JT. 2001. Organisational culture and health care performance: a review of the theory, instruments and evidence. York: Centre for Health Economics, University of York

[18] Mannion R, Davies H, CS., at.al.,. 2010. Changing management cultures and organisational performance in the NHS (OC2). Research report produced for the national institute for health research service delivery and organisation programme.

[19] Mathis, Robert L. dan Jackson, J. H. 2006, Manajemen Sumber Daya Manusia. Jakarta, Salemba Empat.

[20] Miller , Patricia, Work and Family Researchers Network, 2013, Department of Sociology University of Pennsylvania (https://workfamily.sas.upenn.edu/ content/ contact)

[21] Norman, KD \& Lincoln. YS. 1997, Hand Book of Qualitative Research, Pustaka Pelajar. Yogyakarta.

[22] Rao, TV. 1996, Penilaian Prestasi Kerja, Teori dan Praktek. Cetakan Ketiga. Jakarta: PT. Ikrar Mandiri Abadi.

[23] Robbins, PS \& Judge, TA. 2011, Organizational Behavior, $14^{\text {th }}$ edition, PEARSON. Boston.

[24] Scott T, Mannion R, Davies HTO, Marshall MN. 2004, Implementing culture change in health care: theory and practice' International Journal of Quality in Health Care.

[25] Sergey Group, Ltd.,2013, http://www.sergaygroup.com/Smart-Talk/What-is-Corporate-Culture.html

[26] Simamora, Henry, (1999), Manajemen Sumber Daya Manusia, Edisi Kedua, STIE YKPN, Yogyakarta.

[27] Singarimbun,M., S.Efendi, 1995, Metode Penelitian Survay, LP3ES, Jakarta

[28] Soeprihanto, John. 2004. Penelitian Kinerja dan Pengembangan Pegawai. Edisi Pertama. Yogyakarta: BPFE.

[29] Sugiyono. 2010, Memahami Penelitian Kualitatif, Alfabeta. Bandung.

[30] Tamura Makoto, Fukuda Takashi. 1999, An empirical research on a subculture in a health care organization. A research for five hospitals located in a Tokyo metropolitan area. Health Manajement Journal.

[31] Tosi, H.L., Rizzo, J.R. \& Carrol, S.J., 1990, Managing Organizational Behavior, 2nd edition, Harper Collins Publihser. New York.

[32] Truss, at.al. 2013, Employee engagement, organisational performance and individual well-being: exploring the evidence, developing the theory, The International Journal of Human Resource Management, Volume 24, Issue 14

[33] Walton, R.E. 1987. Managing Conflict: Interpersonal Dialogue and Third-Party Roles. $2^{\text {nd }}$ edition, Addison-Wesley Publishing Company. Massachusetts.

[34] Wood, at al, 2001, Organisational Behaviour, a global Perspective $2^{\text {nd }}$ edition, John Wiley \&Sons Australia, Ltd.,Brisbane.

[35] Yupono, Bagyo, 2009, Locus of Contol influence on work motivation, organizational citizenship behavior, commitment and employee performance organissional, dissertation, Brawijaya University

[36] Zinger, David, 2011, www.davidzinger.com/wp-content/uploads/Employee-Engage-ment-Model-Zinger-2011.jpg

[37] http://www.businessdictionary.com/definition/employee-performance.html

[38] (http://www.peoplestreme.com/what-is-performance-management.shtml)

[39] http://www.businessdictionary.com/definition/employee-performance.html

[40] http://www.peoplestreme.com/what-is-performance-management.shtml

[41] http://www.talentkeepers.com/images/EngagedWorkforceModel.png

[42] http://www.uwgb.edu/hr/training/ClassifiedPerformanceReviewSupervisors.pdf

[43] http://en.wikipedia.org/wiki/Employee_engagement. 